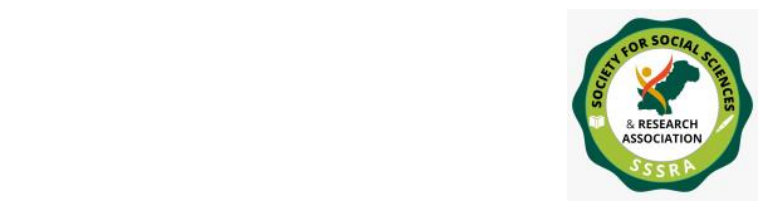

\title{
REVIEW OF "THE CHINA-PAKISTAN AXIS: ASIA'S NEW GEOPOLITICS"
}

\author{
Andrew Small, The China-Pakistan Axis: Asia's New Geopolitics, New \\ York, Oxford University Press, 2015
}

\author{
*Dr. Omme Asma, Head of Research, Jamia tul Mohsanat, Karachi - Pakistan \\ **Dr. Syed Wasimuddin, Former Head, Department of International Relations, Federal \\ Urdu University, Karachi - Pakistan
}

This publication of Andrew Small is a brief however noteworthy record of a relationship amongst Islamic Republic of Pakistan and People's Republic of China and their geopolitical proposition in the district. Small is an English creator and now works at the German Marshall Fund with the Asia program in the USA. He likewise contributed in a couple of daily papers and magazines. Essentially, the book watched out for two liberal subjects. To begin with, it looks to benefit from the states of relations amongst China and Pakistan between the cool war and 2015, and furthermore, it breaks down the geopolitics of South Asia on relations amongst China and Pakistan.

This is an enthralling and needed book on the conventional connection amongst China and Pakistan and a recognized augmentation to the present get-together of overwhelming works identified with Asian authoritative issues. The examination of Small spotlights fundamentally on the association which China shared with Pakistan since 1950s to today and how it has influenced Asian region close to the Indo-Pacific area security. This book gives a point-by-point record of the association among the two nations, focusing on the Goliath and repulsive conditions of the partnership all through the Cold War. Its truth to be told, a staggeringly late book, given that China has been in the news starting late, given its budgetary headway, and Pakistan has turned out to be a basic idea from the Western media for in a general sense security reason.

On account of South Asia, China, India and Pakistan are an imperative gathering of on-screen characters. India and Pakistan make and create monetary issues and China is a propelled economy. Without political power and peace in India and Pakistan, it would be troublesome for China 
to keep up its situation at both the commonplace and all-inclusive levels. The creator said that China needs to be unequivocal and visit in South Asia and India is a test being produced for China. That is the reason China is basically reinforcing and supporting Pakistan as far as assurance, establishments and economy with the possibility of shortening India. Moreover, a large portion of the fiscal and crucial interests are particularly connected to Pakistan. As of late, Afghanistan has likewise developed as a solid player in South Asia. The associations amongst Pakistan and Afghanistan are a mind-blowing worry for China. China is attempting outrageous endeavours to interface access amongst Pakistan and Afghanistan. Since money related flourishing is particularly connected with peace and security, China effectively takes an interest in the dialog with the Taliban. Pakistan, as a Chinese associate, faces extraordinary affliction for China in light of its crucial significance. Pretty much, China needs to adjust vitality in South Asia by disparaging India and fortifying Pakistan, which could in the long run be advantageous to China. In the epilogue, the writer clarifies that China-Pakistan is generally prepared to escape the shadows.

The association amongst China and Pakistan has not been considered by scholastics who have an open door with the Asian security of any educational, and this examination gives a nitty gritty and redress enrolment of this key association. In spite of the fact that the book centres especially around the Pakistan-China organization, it does as such inside a regional setting and past a worldwide situation. Set up the Sino-Pakistani relationship in a near to territory and watch the effect this relationship can have in neighbouring nations, for example, India and Afghanistan. For instance, there is a talk of what that partnership could turn out towards Indian Occupied Kashmir, the zone attempted between Pakistan, China, and India. In such path, there's an essential research on definitive and security issues in India and on the affiliations which India offers to Pakistan and China. The writer in addition interfaces this vital association with neighbouring Afghanistan, and in this setting, there is speedy talk in the book on Afghanistan and on Afghan complete issues. The relationship amongst China and Pakistan makes in an altogether more extensive general setting, surmising the interests of the United States. In the IndoPacific zone and how they have impacted one another. This work will be especially helpful for business students and those profiting from general affiliations and security issues in the Asia-Pacific district. Small in like way presents a one-on-one trade on Islamist gatherings and transcontinental affiliations which offer such social congregations. There 


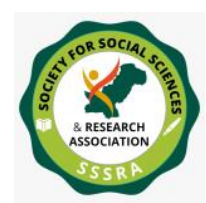

are areas in this book about Taliban and the eastern headway in Turkestan, which is an Islamic mass of the Xinjiang district in northwest China.

Small also offers an understanding of Pakistan's local legislative issues and analyses the Pakistani Army and Inter Service Intelligence (ISI). This book is not only useful for students dealing with government issues and global bonds in Asia Pacific, but it will also be useful for people who are enthusiastic about the legislative and security in South Asia and underproblems. For instance, the essential match of parts gives us a point-topoint war between Sino India in 1962 and the war of 1965 between India and Pakistan. The basic bit of this book surmises Pakistan and India and records China, while the other part is extra fundamental in Afghanistan and the association with Pakistan and China. Small encounters China was conciliator guarantee of Pakistan, whose arms supplier was known as a last resort when the other accomplice left the accumulations.

The book will also be important for companies that accept issues of Chinese authority, particularly those who are passionate about ethnic minority areas of China, such as Xinjiang, also called the Uygur Autonomous Region of Xinjiang. With this in mind, the book explores an incredibly capricious region that allows for a thorough understanding of government, Chinese, Indian, Pakistani, and Afghan problems. Finally, the book includes an illustrative system on the delicate circumstances of security in central and southern Asia. The book gives a huge amount of information on the recorded setting of Pakistan today and on the affiliations that Beijing has got from Islamabad, examination of the book on how the affiliation has influenced the issues of neighbourhood government in Pakistan. The author in like way fights the partnership among the two neighbours has been in fact solid, meanwhile its fundamental to shoulder on a time of noteworthy advance, incorporating the distinction in China to a associate economy to transform into a capitalist economy, the move of Islamic extremism in Afghanistan. The area of Pakistan (AFPAK), and the smaller affiliations that the two states had with the United States and India. An explanation of China's binds with Pakistan was to audit the move of Indian side, that sees China as a potential threat. Pakistan, the country that has been in the fight through itself later 1947, sees the Chinese leadership as a withdrawal from the feebleness in perspective of the money related help that China gives to Pakistan. This help is specifically fundamental afterward the force of NATO powers have pulled back totally from the AFPAK territory. 
In the field, administrative problems, poor respect for everything included or close, there are no permanent employees or endless enemies. In most cases, you will manage and implement the most important objectives. At the end of the day, there are important questions: get and go back. Of course, Andrew Small has made this book, but it is more journalistic than school work. In general, Small's work opens up a space for new discussions and research on the geopolitics of South Asia. The present would be profitable for the substitution of governmental operations in South Asia and for administrative, academic matters all over the world, in particular history, political specialists and currency specialists.

This book is one of the few pieces of work which reveals the confusing and critical connection between Pakistan and China with extraordinary details. In any case, the focal research of Small, regardless of whether Pakistan really has a legendary perspective of its association with China, does not develop and is lost towards the end of the book. Small closures of your book with the following statement:

"China is worried about Pakistan's long-haul future, and the test of managing a nation that is both China's principle wellspring of psychological oppressor risk and its key accomplice in managing this danger is hard to explore. companionship, is a product which Pakistan can bid to China is extra realistic than that by any other nation, is further critical to Beijing than it was before and, accordingly, the Chinese-Pakistani pivot is relatively prepared to leave the kick of the shadows."

While Small refers to official sources claiming that China will not help Pakistan in case a dispute arises, it does not complete this situation to a conclusion and ends with a note of hope. He is relatively reluctant to assert his request so that anyone can listen. In any case, the primacy of Small is a compromise worthy of note for the lack of academic writings on the geopolitical connection between Pakistan and China. 